\title{
Competition with macroalgae and benthic cyanobacterial mats limits phytoplankton abundance in experimental microcosms
}

\author{
Peggy Fong *, Regina M. Donohoe**, Joy B. Zedler \\ Pacific Estuarine Research Laboratory, San Diego State University, San Diego, California 92182-0057, USA
}

\begin{abstract}
Competition for nutrients among estuarine phytoplankton and algal mats (a combination. of floating and attached green macroalgae and attached cyanobacterial mats) was studied using replicate experimental microcosms. At high nutrient loading (nitrate- $N=77 \mu \mathrm{M} \mathrm{d}^{-1}$ ), the growth of phytoplankton was reduced by a factor of 10 in the presence of the algal mats. Without the algal mats the phytoplankton was very abundant $\left(>5 \times 10^{6}\right.$ cells $\left.\mathrm{ml}^{-1}\right)$ and dominated by small flagellates, while in the presence of the algal mats the phytoplankton assemblage was sparse and diatoms, flagellates, and unicellular blue-greens were common. The competition hierarchy was cyanobacterial mats $\gg$ attached green macroalgae $>$ floating green macroalgae $>$ phytoplankton. When nutrient supply rate was low (nitrate- $\mathrm{N}=1.2 \mu \mathrm{M} \mathrm{d}^{-1}$ ), the presence of the algal mats shifted the phytoplankton from flagellates to blue-green algae, but did not affect total biomass of the phytoplankton. We conclude that the attached forms of macroalgae as well as the cyanobacterial mats were better competitors for high levels of nutrients than the phytoplankton. This resource competition may explain the negative correlation found in field studies between phytoplankton and macroalgae growing in shallow nutrient-enriched estuaries.
\end{abstract}

\section{INTRODUCTION}

Ecological theory predicts that competition for limiting resources is very important in structuring natural communities (Roughgarden 1983). Although providing clear and direct evidence of competition under natural conditions is difficult (Connell 1980, Simberloff 1983), there has been some success in laboratory experiments. Resource competition was established between pairs of planktonic algal species in continuous culture chemostats (Tilman \& Kilham 1976, Tilman 1977). These experiments showed that resource competition can structure simple laboratory 'communities', and that the outcome of competition may change along a

Present addresses:

- Rosenstiel School of Marine and Atmospheric Science, University of Miami, 4600 Rickenbacker Causeway, Miami, Florida 33149, USA

- Oregon State University, Department of Fisheries and Wildlife, Corvallis, Oregon 97331, USA nutrient gradient. Competition between species of macroalgae has also been established (Carpenter 1990, Maggs \& Cheney 1990, Olson \& Lubchenco 1990, Paine 1990). However, few studies address competition between different groups of algae (but see Smith \& Horne 1988). In general, benthic and water column primary producers are treated independently.

The goal of this experiment is to test whether competition for nutrients can occur among 3 morphologically diverse groups of algae. These groups commonly co-occur in shallow coastal lagoons, forming spatially and temporally complex communities in many geographical locations, including southern California, USA (Fong 1986, Peters et al. 1986, Rudnicki 1986), Rhode Island, USA (Lee \& Olsen 1985), Western Australia (Gordon \& McComb 1989), and South Africa (Day et al. 1989). The 3 groups include macroalgae, phytoplankton, and cyanobacterial mats with associated epiphytes. Both macroalgae and cyanobacterial mats form attached algal mats; however, under certain conditions, macroalgal mats can detach and float 
(Smith 1947, Pickett-Heaps 1975, Moss \& Marshland 1976). The dominant macroalgae are usually foliose members of the Division Chlorophyta, in the genera Cladophora, UIva or Enteromorpha. Typically, dominant phytoplankton include small $(<5 \mu \mathrm{m})$ blue-green unicells, Naviculoid diatoms, and several types of flagellates (Fong 1986, Day et a]. 1989). Epipsammic and epipelic associations of mat-forming blue-green algae include the genera Oscillatoria, Microcoleus, and Anabaena, and their epiphytes, usually pennate diatoms (Zedler 1982, M. E. Kentula unpubl. data).

Correlative evidence suggests resource competition between algal groups occurs in shallow semi-enclosed systems where the groups remain in proximity for an extended time. When Marshall \& Orr (1949) fertilized a shallow English sea loch they found that phytoplankton only bloomed when macroalgae were not present. In a year-long field survey of Tijuana Estuary, southern California, Fong (1986) and Rudnicki (1986) also found a negative correlation between the abundance of macroalgae and phytoplankton; abundance of both groups varied spatially and seasonally. Lee \& Olsen (1985) found that rapid benthic macroalgal growth in shallow Rhode Island lagoons resulted in low watercolumn nutrient concentrations despite high loading rates; they hypothesized that macroalgae were able to depress phytoplankton populations. One manipulative experiment (Smith \& Horne 1988) established the link between the presence of Ulva spp. and lower phytoplankton biomass in microcosms simulating San Francisco Bay (California). In outdoor microcosms modeling coastal lagoons, we determine if macroalgae and filamentous mats of cyanobacteria compete with phytoplankton for limiting nutrients.

\section{METHODS}

The effect of 2 factors on phytoplankton yield, (1) rate of nutrient addition and (2) the presence or absence of algal mats (green macroalgae and cyanobacterial mats), was determined in replicate experimental microcosms. Microcosms were 100 l plastic drums, $0.58 \mathrm{~m}$ in diameter and $0.64 \mathrm{~m}$ deep, lined with polyethylene bags and installed at the Pacific Estuarine Research Laboratory (PERL), adjacent to the Tijuana Estuary just north of the United States - Mexico border. We chose to conduct the experiment in this outdoor facility to maintain more 'natural' environmental conditions than can be established in a laboratory

Microcosms were inoculated with the different groups of algae (Table 1) on July 14, 1986. Because of the difficulty in maintaining phytoplankton-free treatments in outdoor systems and removing the epiphyte load from macroalgae, only the effect of macroalgae with cyanobacterial mats on phytoplankton was determined; there was no treatment where macroalgae or mats were grown alone. All treatment microcosms were inoculated with phytoplankton while only half were inoculated with macroalgae and associated epiphytes. Microcosms were subjected to 2 levels of nutrient addition; nitrogen and phosphorus were added in a 15:1 ratio to match phytoplankton metabolic demand (Redfield 1958). There were 4 'control' microcosms that were low nutrient seawater without any nutrient addition, but with the complete community. Replication was 4 -fold, resulting in 20 microcosms. The experiment was continued for $61 \mathrm{~d}$

One week prior to the initiation of each experiment, Enteromorpha spp, and cyanobacterial mats were collected from San Elijo Lagoon (San Diego County, California). The algae were grown in low-nutrient seawater to minimize variability in macroalgal growth due to nutrient storage. Fujita (1985) found that when Enteromorpha spp. and Ulva actuca were starved for nitrogen for 6 to $10 \mathrm{~d}$, growth became independent of nutrient history. At the beginning of the experiment, masses of algae (macroalgae + mats) were blotted dry, divided into $5 \mathrm{~g}$ (wet wt) subsamples, and added to each unit. Unfiltered water with phytoplankton was collected from San Elijo Lagoon; each microcosm was inoculated with a $250 \mathrm{ml}$ subsample. Initial chlorophyll a concentration in each microcosm was $1.82 \mu \mathrm{g} \mathrm{l}^{-1}$ ( $\mathrm{SE}=0.08$ ); the dominant phytoplankter (>99\% of the $5 \times 10^{6}$ cells $\mathrm{ml}^{-1}$ ) was a flagellate, $<10 \mu \mathrm{m}$ diameter.

Microcosms were filled with 851 of seawater from the Scripps Institution of Oceanography pier and 151 of freshwater from the city water supply to give a final salinity of $30 \mathrm{ppt}$. Salinity in each microcosm was monitored every $3 \mathrm{~d}$; we added approximately 1 to 21 of freshwater to maintain the salinity at $30 \pm 2$ ppt.

Table 1 Experimental design. In addition, there was a 'control' treatment with no nutrient addition and all 3 groups (phytoplankton, macroalgae, and cyanobacterial mats). Nutrients were added every $3 \mathrm{~d}$. Each treatment was replicated 4 times, for a total of 20 microcosms. N: nitrogen; P: phosphorus

\begin{tabular}{llll|}
\hline $\begin{array}{l}\text { Community } \\
\text { Composition }\end{array}$ & & \multicolumn{2}{c|}{$\begin{array}{c}\text { Nutrient loading rate } \\
\left(\mathrm{mg} \mathrm{I}^{-1} \mathrm{~d}^{-1}\right)\end{array}$} \\
& & Low & High \\
\hline All groups & $\mathrm{N}$ & 0.017 & 1.080 \\
& $\mathrm{P}$ & 0.0025 & 0.160 \\
Phytoplankton alone & $\mathrm{N}$ & 0.017 & 1.080 \\
& $\mathrm{P}$ & 0.0025 & 0.160 \\
All groups (control) & $\mathrm{N}$ & 0.0 & \\
& $\mathrm{P}$ & 0.0 & \\
& & & \\
\hline
\end{tabular}


Although salinities in natural lagoons may vary greatly in summer, we chose to hold salinity constant to isolate the experimental factors. There is evidence that salinity changes do not affect phytoplankton net productivity (Fong 1986), and that seawater or slightly hyposaline water favors macroalgal growth (Rudnicki 1986).

Concentrated stock solutions of nitrate and orthophosphate were added in appropriate amounts to each microcosm every 3 d (Table 1). Contents were thoroughly mixed at this time. Nutrient additions are within the range measured entering several lagoons in southern California (Peters et al. 1986); these lagoons are highly eutrophic. Sediments, important sources and sinks of nutrients in natural systems, were not included in the microcosms so that any added nutrients remained in the water column or were incorporated into biomass. Omitting sediments enabled us to focus on algal interactions under known nutrient loading rates rather than confound the relationships with storage or release from the sediments.

We monitored several environmental parameters during the experiment. Photosynthetically active radiation was typical for July in southern California (afternoon maximum range $=900$ to $2200 \mu \mathrm{E} \mathrm{m}^{-2} \mathrm{~s}^{-1}$; mean $=$ $1800 \mu \mathrm{E} \mathrm{m}^{-2} \mathrm{~s}^{-1}$ ). Fiberglass screening was placed over the tanks to reduce colonizing insects, attenuating approximately $30 \%$ of the incident light and reducing the average afternoon maximum to ca $1000 \mu \mathrm{E} \mathrm{m}^{-2} \mathrm{~s}^{-1}$ entering the microcosms. High concentrations of chlorophyll in microcosms with high nutrient addition and phytoplankton alone probably resulted in limited light penetration and phytoplankton may have been self shading; when chlorophyll levels in Tijuana Estuary were $>100 \mu \mathrm{g} \mathrm{l}^{-1}$, light was reduced by $>95 \%$ at a depth of $0.5 \mathrm{~m}$ ( $\mathrm{n}=5$; Fong unpubl. data). However, light was probably not limiting macroalgae or mats in any of the microcosms because chlorophyll never exceeded $10 \mu \mathrm{g} \mathrm{l}^{-1}$ when these groups were present. In Tijuana Estuary, this amount of chlorophyll typically reduced light by about $50 \%$ at $1 \mathrm{~m}$ of depth ( $\mathrm{n}=15$; Fong unpubl. data); in July, this would result in light levels at the bottom of the microcosms in the range of ca $500 \mu \mathrm{E} \mathrm{m}^{-2} \mathrm{~s}^{-1}$. Growth of Enteromorpha spp., the green macroalga in the microcosms, is saturated by light levels of $300 \mu \mathrm{E} \mathrm{m} \mathrm{m}^{-2} \mathrm{~s}^{-1}$ (Fujita 1985) while cyanobacterial mats saturate slightly higher (M. E. Kentula unpubl. data). Temperatures in the microcosms were similar to concurrent lagoon temperatures; afternoon readings ranged from 24 to $29^{\circ} \mathrm{C}$ with a diel change of 2 to $8^{\circ} \mathrm{C}$. Faunal samples were taken from each microcosm at harvest to assess the potential impact of grazing. Diversity was very low and most of the animals were detrital feeders or microalgal scrapers (Scintila Almeida Por, Hebrew University of Jeru- salem, pers. comm.); these may affect the abundance of mats, but would not affect phytoplankton.

Abundance of phytoplankton was estimated by chlorophyll a concentration. To measure chlorophyll $a$, a $100 \mathrm{ml}$ water sample was taken from each microcosm after thorough mixing. The samples were filtered in the field with Whatman GF/C glass fiber filters and stored on ice in the dark for a maximum of $8 \mathrm{~h}$. Upon return to the laboratory, filters were placed in a plastic bag in a dark desiccator at $-20^{\circ} \mathrm{C}$ for 1 to $20 \mathrm{~d}$. Extraction of chlorophyll pigments and fluorometric analyses were performed using the method of Lorenzen (1967) as modified by Holm-Hansen \& Rieman (1978). Additional samples were collected and fixed with Lugol's solution (Sournia 1978). Cells were settled onto chambers and counts made through an inverted phase-contrast microscope. Dominance was calculated as percentage of the total number of cells.

Biomass of attached algae was estimated from algae growing on glass slides. Slides $(75 \times 25 \mathrm{~mm})$ were attached to a plastic cord that was suspended horizontally in the water column. All slides were at the same depth but varied in their distance from the edge. Visual estimates of the abundance of algae on the slides and the plastic bag covering the bottom and sides of the microcosm were not different. At harvest, 3 slides were randomly removed from each microcosm and visual estimates of relative percent cover of the algae (macrophytic greens or filamentous blue-greens) performed; cover was estimated to the nearest $10 \%$. Slides were rinsed briefly in fresh water, wrapped in foil, dried at $105^{\circ} \mathrm{C}$ for $72 \mathrm{~h}$, and weighed (APHA 1980). The weight of the slide after both sides were scraped with a razor blade was subtracted from the weight of the slide before scraping. This produced an estimate of dry weight per unit area, which was converted to dry weight per microcosm by multiplying by the surface area $\left(1.429 \mathrm{~m}^{2}\right)$ of the inside of the microcosm. The estimated biomass for green macroalgae was subtracted from the total weight of the attached algae; the difference estimated the dry weight of the cyanobacterial mats.

At harvest, the entire content of each microcosm was poured through a $5 \mathrm{~mm}$ mesh net to collect all the floating macroalgae. The algae were rinsed, wrapped in aluminum foil, and placed in a forced-air oven at $105^{\circ} \mathrm{C}$ until constant weight (about $72 \mathrm{~h}$; APHA 1980). This biomass (dry weight per aquarium) was recorded as the 'floating' macroalgae. The biomass of benthic green algae estimated as indicated in the previous section was recorded as the 'attached' macroalgae.

A 2-factor ANOVA was done on the chlorophyll a concentration from the final sampling date (Day 61). A protected least significant difference test (PLSD) was performed on the final biomass of macroalgae and mats to detect differences in the means. 


\section{RESULTS}

Both nutrients and the presence of the other algal groups significantly affected the biomass of phytoplankton in the experimental microcosms (2-factor ANOVA at harvest: $p<0.01$ ). In addition, there was significant interaction between the 2 factors $(p<0.01)$. When nutrient addition was high and macroalgae and cyanobacterial mats were excluded, maximum mean

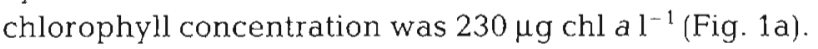
Biomass increased through time and variability was low (coefficient of variation, CV, $<20 \%$ ). In the treatments where nutrient addition was high and macroalgae and cyanobacterial mats were present, chlorophyll a concentration was low, never exceeding $15 \mu \mathrm{g}$ chl a $\mathrm{I}^{-1}$. When nutrient addition was high, the presence of macroalgae and mats significantly limited phytoplankton biomass, suggesting macroalgae and mats were better competitors when nutrient supply was greater.
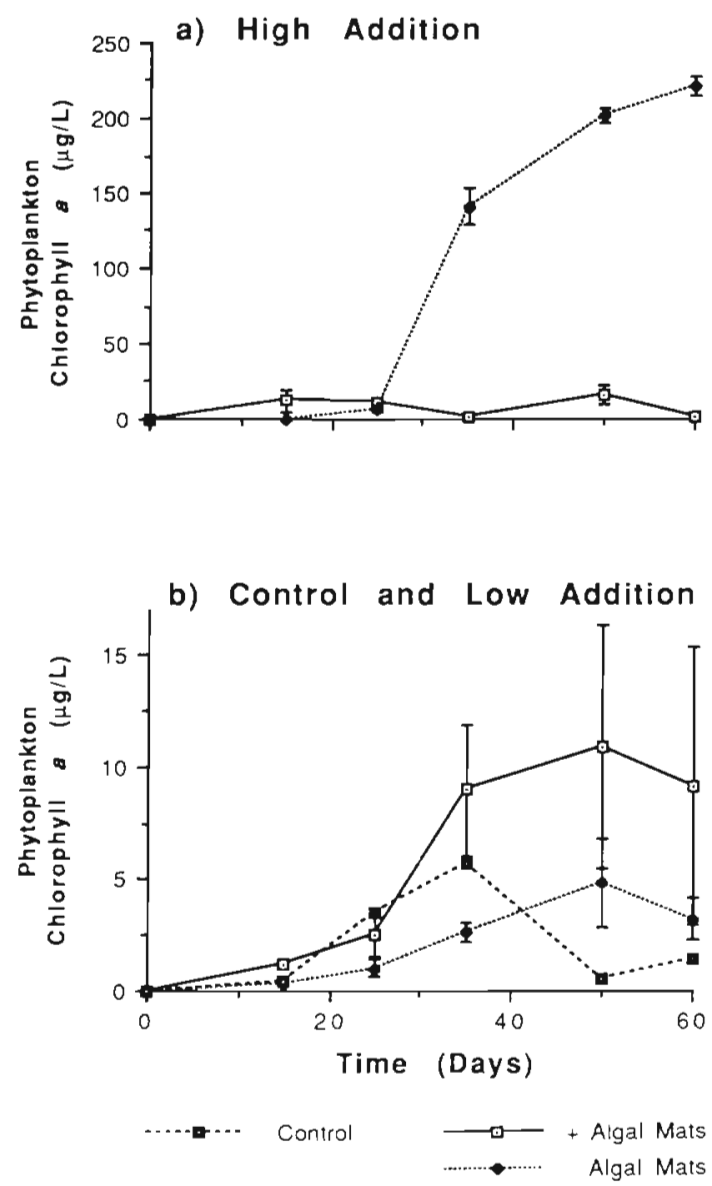

Fig. 1. Chlorophyll a concentration of phytoplankton in the microcosms during the $60 \mathrm{~d}$ experiment in all of the experimental treatments. \pm Algal Mats: presence or absence of macroalgae + cyanobacterial mats. $n=4$; error bars are $\pm S E$
Table 2. Phytoplankton dominance in each experimental treatment after $61 \mathrm{~d}$. Dominance is quantified as \% of the total number of cells. Low and high refer to nutrient addition rates and \pm algal mats to the presence or absence of macroalgae and cyanobacterial mats. Values are means (SE)

\begin{tabular}{|lrrr|} 
& Diatoms & Flagellates & $\begin{array}{r}\text { Blue-green } \\
\text { unicells }\end{array}$ \\
\hline Control & $0.5(0.23)$ & $0.5(0.50)$ & $99.0(3.5)$ \\
Low, -algal mats & $1.0(0.12)$ & $99.0(0.76)$ & $0.0(0.0)$ \\
Low, + algal mats & $0.5(0.50)$ & $0.5(0.50)$ & $99.0(1.6)$ \\
High, - algal mats & $2.0(2.00)$ & $98.0(1.90)$ & $0.0(0.0)$ \\
High, +algal mats & $51.0(16.9)$ & $26.0(7.50)$ & $23.0(6.8)$ \\
\hline
\end{tabular}

There were no significant differences in final chlorophyll a concentration between the control, both low addition rates, and the high addition rate with macroalgae and cyanobacterial mats (PLSD; $\mathrm{p}<0.05$ ). When nutrient addition was low or ambient (control), mean chlorophyll a concentration was low throughout the entire $61 \mathrm{~d}$ experiment, regardless of the presence of the macroalgae and cyanobacterial mats (Fig. 1b). The presence of the macroalgae and cyanobacterial mats did not reduce phytoplankton abundance when nutrients were low, suggesting phytoplankton were better competitors when nutrient supply was low. In the low nutrient treatments and the control, maximum mean biomass never exceeded $12 \mu \mathrm{g}$ chl a $\mathrm{l}^{-1}$, while the CV ranged from 10 to $100 \%$. Despite constant nutrient addition rates in the low treatments, there were no patterns of increasing phytoplankton biomass through time; rather the temporal trends were characterized by transient maxima and high variability.

In both high and low nutrient treatments, the presence of the macroalgae and cyanobacterial mats affected the composition of the phytoplankton assemblage. When the other algal groups were excluded, phytoplankton numbers were dominated by the same small flagellate (Table 2) that dominated the inoculum taken from San Elijo Lagoon. Cell density was dependent on nutrient addition; there were $9 \times 10^{4} \mathrm{cells} \mathrm{m}^{-1}$ when addition was low and $5 \times 10^{6}$ cells $\mathrm{ml}^{-1}$ with high addition, nearly a 1.00 -fold increase. In the microcosms where macroalgae and mats were included, the phytoplankton shifted composition. The control and low nutrient addition microcosms were dominated by small cyanobacteria while there was a mixed assemblage of diatoms, flagellates, and blue-green unicells in the high nutrient treatment.

Nutrient addition stimulated both cyanobacterial mats and attached macroalgae when these groups were present (PLSD, $p<0.05)$. Mean biomass of mats was $30 \mathrm{~g} \mathrm{microcosm}^{-1}$ in the high nutrient treatment, but less than $5 \mathrm{~g} \mathrm{microcosm}^{-1}$ in the control and low 


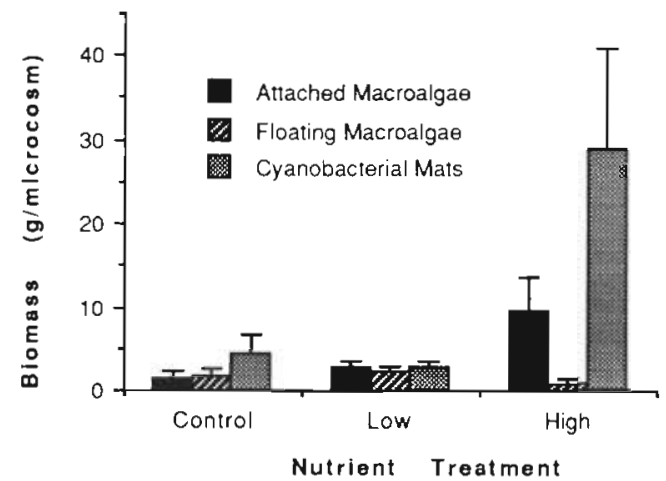

Fig. 2. Biomass of the floating and attached macroalgae and cyanobacterial mats grown with phytoplankton for $61 \mathrm{~d}$ in the experimental treatments. $n=4$; error bars are $+\mathrm{SE}$

addition (Fig. 2). Biomass of attached macroalgae was also higher in the high nutrient treatment: $11 \mathrm{~g}$ micro$\cos m^{-1}$ in the high nutrient treatment and $<4 \mathrm{~g}$ micro$\cos ^{-1}$ in either the control or low nutrient treatment. There were no significant differences between treatment means for floating macroalgae.

\section{DISCUSSION}

Our experiment provides evidence that resource competition can occur between benthic and water column primary producers. The strength of the interaction depends on the supply rate of the resource. When nutrient addition rate was high, phytoplankton biomass was an order of magnitude higher in the absence of macroalgae and cyanobacterial mats. In treatments where macroalgae and mats were present, they were stimulated (2- to 6 -fold increases in biomass) by high nutrient addition. When addition was low, phytoplankton was not affected by competition with the other groups.

Compositional changes within the phytoplankton assemblage may be explained by invoking competition. Competition theory predicts that the intensity of competition should be highest in microcosms where nutrient supply was low and macroalgae and cyanobacterial mats were present. In our experiment, this strong competition favored small blue-green unicells with large surface area to volume ratios that have an advantage under low nutrient conditions (Grover 1989). When nutrient addition was higher, the composition of the phytoplankton was mixed, indicating that nutrients were not as scarce.

We suggest that the outcome of competition changed along the nutrient supply gradient, with phytoplankton 'winning' when supplies were low and macroalgae and mats 'winning' when supplies were high. This is supported by uptake parameter values calculated from nutrient uptake experiments. Algae with lower halfsaturation constants $\left(K_{5}\right)$ are better competitors when nutrient supply is low while algae with high maximum uptake rates ( $V_{\max }$ ) have the advantage when nutrient supply is high. Fong et al. (1993) found that, in general, nitrogen limits the algal community in southern California lagoons. $K_{5}$ values for nitrogen measured for Enteromorpha range widely $\left(0.057\right.$ to $0.336 \mathrm{mg} \mathrm{N}^{-1}$; Harlin 1978, Kautsky 1982, Fujita 1985, O'Brien \& Wheeler 1987), with the lowest values reported for ammonium uptake in nutrient starved cultures. $K_{\mathrm{s}}$ values for phytoplankton range from 0.0014 to $0.018 \mathrm{mg} \mathrm{N}^{-1}$ (Eppley \& Thomas 1969, Garside \& Glover 1991), an order of magnitude lower than the green macroalga. $V_{\max }$ for Enteromorpha ranges from 0.03 to 0.44 for nitrate (Harlin 1978. Thomas et al. 1987) and 0.04 to $0.64 \mathrm{mg} \mathrm{N} \mathrm{g}^{-1}$ dry wt $\mathrm{d}^{-1}$ for ammonium (O'Brien \& Wheeler 1987). Values of $V_{\max }$ for phytoplankton are difficult to compare to macroalgae, because they are rarely calculated on a dry weight basis.

We hypothesize that the strength of resource competition among different algal groups is also dependent on the amount of physical coupling between the groups. In our microcosms, there was a high surface area for attached algae to colonize compared to the water volume and therefore a large physical area for benthic and water column algae to interact. This is also the case in shallow lagoonal systems, where there is more sediment surface area available for benthic forms of algae. Interaction between benthic and water column primary producers is probably not as important in deeper systems where the benthic/water column coupling is not as extensive, or in areas with high turbidity where the benthos is more likely to be light-limited.

An alternative explanation for our results may be allelopathic interactions between phytoplankton and either macroalgae or cyanobacterial mats. Freshwater cyanobacteria are known to produce chemical inhibitors that act on other cyanobacteria and to a lesser extent on members of the Chlorophyceae (Gross et al. 1991). However, Smith \& Horne (1988) found no allelochemical effects of UIva exudates on phytoplankton of San Franciso Bay. In our experiment, there is no indication of suppressed phytoplankton growth in the presence of macroalgae or cyanobacterial mats in the control or the low nutrient addition treatments, which indicates resource limitation rather than toxic effects.

We conclude that macroalgae and mats of cyanobacteria were better competitors for nutrients at elevated supply rates than the phytoplankton assemblage in the microcosms, and hypothesize that resource competition may explain the negative correlation between macroalgae and phytoplankton observed in shallow, enriched natural systems (Marshall \& Orr 1949, Lee \& Olsen 1985, Fong 1986, Gordon \& McComb 1989). 
Acknowledgements. This research was funded in part, by the California State Water Resources Control Board with grant funds made available by the United States Environmental Protection Agency and the San Diego Association of Governments. Additional support was provided by San Diego State University. The writing phase of this project was funded by a grant from the National Sea Grant College Program, National Oceanic and Atmospheric Administration, U.S Department of Commerce, under grant number NA89AA-DSG138, through the California Sea Grant College Graduate Research Fellowship Program. The views expressed herein are those of the authors and do not necessarily reflect the views of NOAA or any of its sub-agencies.

\section{LITERATURE CITED}

APHA (American Public Health Association) (1980). Standard methods for the examination of water and wastewater American Public Health Association, New York

Carpenter, R. C. (1990). Competition among marine macroalgae: a physiological perspective. J. Phycol 26: 6-12

Connell, J. H. (1980). Diversity and coevolution of competitors, or the ghost of competition past. Oikos 35 $131-138$

Day, J. W. Jr, Hall, C. H. S., Kemp, W., Yanez-Arancibia, A. (1989). Estuarine ecology. John Wiley and Sons, New York

Eppley, R. W. Thomas, W. H. (1969). Comparison of half-saturation constants for growth and nitrate uptake of marine phytoplankton. J. Phycol. 5: 375-379

Fong, P. (1986). Monitoring and manipulation of phytoplankton dynamics in a Southern California estuary. M.Sc. thesis, San Diego State University, San Diego

Fong, P., Zedler, J. B., Donohoe, R. M. (1993). Nitrogen versus phosphorus limitation of algal biomass in shallow coastal lagoons. Limnol. Oceanogr. (in press)

Fugita, R. (1985). The role of nitrogen status in regulating transient ammonium uptake and nitrogen storage by macroalgae. J. exp. mar. Biol. Ecol. 92: 283-301

Garside, C., Glover, H. E. (1991). Chemiluminescent measurements of nitrate kinetics: 1 Thalassiosira pseudonana (clone $3 \mathrm{H}$ ) and neritic assemblages. J. Plankton Res. 13: $5-19$

Gordon, D. M., McComb, A. J. (1989). Growth and production of the green alga Cladophora montagneana in a eutrophic Australian estuary and its interpretation using a computer program. Wat. Res. 23: 633-64.5

Gross, E. M., Wolk, C. P., Juettner, F. (1991). Fischerellin, a new allelochemical from the freshwater cyanobacterium Fisherella muscicola. J. Phycol. 27: 686-692

Grover, J. P. (1989). Influence of cell shape and size on algal competitive ability. J. Phycol. 25: 402-405

Harl.n, M. M. (1978). Nitrate uptake by Enteromorpha spp. (Chlorophyceae): applications to aquaculture systems. Aquaculture 15: 373-374.

Holm-Hansen, O., Rieman, B. (1978). Chlorophyll determination: improvements in methodology. Oikos 30:438-447

Kautsky, L. (1982). Primary productivity and uptake kinetics of ammonium and phosphate by Enteromorpha compressa in an ammonium sulfate industry outlet area. Aquat. Bot. 12: $23-40$

This article was presented by J. A. West, Berkeley, California, USA
Lee, V., Olsen, S. (1985). Eutrophication and management initiatives for the control of nutrient inputs to Rhode Island coastal lagoons. Estuaries 8: 191-210

Lorenzen, C. J. (1967). Determination of chlorophyll and phaeopigment: spectrophotometric equations. Limnol. Oceanogr. 12: 343-346

Maggs, C. A, Cheney, D. P. (1990). Competition studies of marine macroalgae in laboratory culture. J. Phycol. 26: $18-24$

Marshall, S., Orr, A. (1949). Further experiments of fertilization of a sea loch: the effects of different plant nutrients on phytoplankton. J. mar. biol. Ass. U.K. 27: 360-379

Moss, B., Marshland, A. (1976). Regeneration of Enteromorpha. Brit. Phycol. J 11:309-313

O'Brien, M. C., Wheeler, P. A. (1987). Short term uptake of nutrients by Enteromorpha prolifera (Chlorophyceae). J. Phycol. 23: 547-556

Olson, A. M., Lubchenco, J. (1990). Competition in seaweeds: linking plant traits to competitive outcomes. J. Phycol. 26: $1-6$

Paine, R. T. (1990). Benthic macroalgal competition: complications and consequences. J. Phycol. 26; 12-17

Peters, G., Paznopkas, W., Noyes, V. (1986). A review of nutrient standards for the coastal logoons in the San Diego region. California Regional Water Quality Control Board Report, San Diego

Pickett-Heaps, J. D. (1975). Green algae: structure, reproduction, and evolution in selected genera. Sinauer Associates, Sunderland, $M A$

Redfield, A. C. (1958). The biological control of the chemical factors in the environment. Am. Sci. 46: 205-230

Roughgarden, J. (1983). Competition and theory in community ecology. Am. Nat. 122: 583-601

Rudnicki, R. (1986). Dynamics of macroalgae in Tijuana Estuary: response to simulated wastewater addition. M.Sc. thesis, San Diego State University, San Diego

Simberloff, D. (1983). Competition theory, hypothesis-testing, and other community ecological buzzwords. Am. Nat. 1.22: $626-635$

Sournia, A. (1978). Phytoplankton manual. UNESCO, Paris

Smith, G. (1947). On the reproduction of some Pacific Coast species of Ulva. Am. J. Bot. 34: 80-87

Smith, D. W. Horne, A. J. (1988). Experimental measurement of resource competition between planktonic microalgae and macroalgae (seaweeds) in mesocosms simulating the San Francisco Bay-Estuary, California. Hydrobiologia 159: $259-268$

Thomas, T E., Turpin, D. H., Harrison, P. J. (1987). Desiccation enhanced nitrogen uptake rates in intertidal seaweeds. Mar. Biol. 94: 293-298

Tilman, D. (1977). Resource competition between planktonic algae: an experimental and theoretical approach. Ecology 58: $338-348$

Tilman, D., Kilham, S. S. (1976). Phosphate and silicate growth and uptake kinetics of the diatoms Asterionella formosa and Cyclotella meneghiniana in batch culture and semicontinuous culture. J. Phycol. 12: 375-383

Zedler, J. B. (1982). The ecology of southern California coasta] salt marshes: a community profile. U.S. Fish and Wildifie Service, Biological Services Program, Washington, DC FWS/OBS-81/54

Manuscript first received: January 27, 1993

Revised version accepted: June 29, 1993 